\title{
Cowboys in the Middle East: Private Security Companies and the Imperfect Reach of the United States Criminal Justice System
}

\section{Christopher M. Kovach ${ }^{*}$}

Mercenaries are dangerously unreliable. According to Machiavelli, employing mercenaries or foreign troops "limited freedom of action and created dependence on other powers." "Yet for the first time in its history, and despite cautionary words against condottieri, the United States is relying heavily on private firms to provide security services in an unstable environment. ${ }^{2}$ In fact, not since the seventeenth century has there been "such a reliance on private military actors to accomplish tasks directly affecting the success of military engagements." "3 But military excursions to foreign soil raise perennial issues related to the imposition of order, discipline, and training, the foundations upon which commanders traditionally build successful campaigns. ${ }^{4}$

Waging war with a combination of regular troops and private security company (PSC) contractors can be done; however, at times the contractors act at cross-purposes with the stated objectives of the campaign. Abuses by PSCs in the recent wars in Iraq and Afghanistan have, according to some analysts, undermined the mission. ${ }^{5}$ Local inhabitants are not the only people who object to these incidents. Regular troops do so as well; discipline suffers. And even the President of the United States, before assuming the responsibilities of commander-in-chief of the nation's armed forces, presciently noted that "we cannot win a fight for hearts and minds when we outsource critical missions to unaccountable contractors."

Christopher M. Kovach serves as a Captain in the United States Air Force Judge Advocate General's Corps. He is presently assigned as Contracts Attorney, Kadena Air Base, Okinawa, Japan.

1 Peter Paret, ed., Makers of Modern Strategy from Machiavelli to the Nuclear Age (Princeton, NJ: Princeton University Press 1986), 19.

2 Jennifer K. Elsea, Mosche Schwartz, and Kennon H. Nakamura, Private Security Contractors in Iraq: Background, Legal Status, and Other Issues, Congressional Research Service Report No. RL32419 (Washington, D.C.: Congressional Research Service, updated $28 \mathrm{Au}-$ gust 2008), 1.

3 Ibid., 2; quoting Fred Schreier and Marina Caparini, Privatising Security: Law, Practice and Governance of Private Military and Security Companies, Occasional Paper 6 (Geneva: DCAF, March 2005), 1.

Mosche Schwartz, The Department of Defense's Use of Private Security Contractors in Iraq and Afghanistan: Background, Analysis, and Options for Congress, Congressional Research Service Report No. R40835 (Washington, D.C.: Congressional Research Service, updated 29 September 2009); citing David Zucchino, "Private Security Forces Unnerve Afghans," Chicago Tribune (17 August 2009).

6 Ibid., quoting C. Hauser, "New Rules for Contractors are Urged by Two Democrats," New York Times (4 October 2007). 
The issue of accountability remains salient. While the United States' criminal justice system has made strides toward holding PSCs accountable - namely by extending military court-martial jurisdiction over PSC troops and permitting federal district courts in the United States to try certain crimes committed abroad - these advances do not go far enough. Haling civilians before courts-martial may be unconstitutional, and the framework for bringing accused criminals back to the U.S. is rarely used. Ultimately, these approaches ignore the military need for swift, visible punishment; the lack of teeth also sends the dangerous message to troops that tossing off a uniform leads to a tripling of one's salary and freedom from obeying those pesky laws of war.

This article explores how to prevent that from happening. The first section details the perceived impunity to the law enjoyed by PSCs and its effect on regular troops in Iraq and Afghanistan. The second section discusses how to bring PSCs before the law through an examination of the relevant international law. It also critiques two expansions to the U.S. criminal justice system - bringing contractors before courts-martial under the Uniform Code of Military Justice or before federal district courts via the Military Extraterritorial Jurisdiction Act — and explains their ineffectiveness. The essay concludes by suggesting that Congress should energize the Military Extraterritorial Jurisdiction Act by funding a dedicated district court to receive its cases. It should also encourage the Department of Justice to liaise with the armed forces to better prosecute those cases. Although bringing civilians before courts-martial is an option, the potential constitutional infirmities make it a bad choice for today's commander in the field.

\section{PSC Contractors as Modern-Day Cowboys}

Blackwater USA, a PSC under contract with the United States and with the consent of the Iraqi government, had provided armed security personnel to protect U.S. Department of State officials in Iraq for several years following the beginning of the Second Iraq War in 2003. On 16 September 2007, after dropping off State Department officials under their protection, Blackwater guardsmen traveled to Nisoor Square in Baghdad. There, without provocation, they began firing indiscriminately into a crowd of unarmed civilians; seventeen Iraqis were killed or wounded. ${ }^{7}$ According to United States Secretary of Defense Robert Gates, contractors like these often operate at "cross purposes" with military goals; he also suggested they be placed under his direct authority, evidencing obvious frustration. ${ }^{8}$

7 In the interests of disclosure, the author previously submitted a memorandum to an attorney working on a civil lawsuit against Blackwater. The thrust of their case, Atban v. Blackwater $U S A$, is whether the norm against extrajudicial killing is sufficiently defined to support both jurisdiction and a cause of action under the Alien Tort Statute, 28 U.S.C. $\S 1350$ (2004), which would allow those families to sustain a claim for wrongful death. I argued yes.

Elsea, Schwartz, \& Nakamura, Private Security Contractors in Iraq, 12; quoting Karen DeYoung, "State Department Struggles to Oversee Private Army," Washington Post (21 October 2007), A1. 
Military officials concurred, stating that PSCs were often "out-of-control cowboys who alienated the same Iraqis the military is trying to cultivate." " But if contractors are cowboys, then Iraq itself must be the Wild West, reborn in the Middle East. As of June 2009, there were 15,279 PSCs in Iraq alone, of which 87 percent were armed. ${ }^{10}$ In Afghanistan, there were 5,198 PSCs, of which 99 percent were armed. ${ }^{11}$ With guns and stress comes the inevitable exchange of gunfire, and the accompanying disastrous implications for foreign policy.

According to one Iraqi Interior Ministry official, the Blackwater incident in Nisoor Square, combined with the company's attitude in ignoring Iraqi law and customs, explained the ordinary Iraqi's hatred for Americans. Essentially, Iraqis cannot distinguish between PSCs and regular troops; they both wear body armor and carry firearms. ${ }^{12}$ (In fact, PSCs at times carry better equipment than U.S. servicemen.) More importantly, the U.S. government's inability or unwillingness to act on these incidents "makes it difficult to advocate for such issues as the importance of the rule of law and human rights...."13

When military members deployed abroad commit misconduct that leads to negative effects "ranging from degraded morale and unit cohesion to strategic impacts that can jeopardize entire campaigns," commanders enforce good order and discipline ${ }^{14}$ through the Uniform Code of Military Justice (UCMJ). ${ }^{15}$ However, as usage of PSCs becomes more prevalent on foreign soil, the need for an effective way to address misconduct increases. One commentator notes that "the lack of transparency and accountability for security contractor operations, particularly the lack of legal options for prosecuting egregious misconduct, have significantly damaged our efforts in Iraq and put our troops at greater risk."

In addition to these high-level strategic concerns, the relative impunity PSCs enjoy also affects the recruitment, morale, and readiness that regular troops face. The lawlessness with which they are able to operate impacts and undercuts civil-military relations in three ways.

First, strengthening the private military industry disrupts the state's monopoly on the use of force abroad and may also lead to destabilizing effects between the state and

9 Ibid., quoting Sudarsan Raghavan and Thomas E. Ricks, "Private Security Puts Diplomats, Military at Odds," Washington Post (26 September 2007), A1.

10 Schwartz, The Department of Defense's Use of Private Security Contractors in Iraq and Afghanistan, 6.

11 Ibid., 8.

12 Steve Fainaru, “Where Military Rules Don't Apply: Blackwater's Security Force in Iraq Given Wide Latitude by State Department," Washington Post (20 September 2007), A1.

13 Elsea, Schwartz, \& Nakamura, Private Security Contractors in Iraq, 13.

14 Stephen P. Cullen, "Out of Reach: Improving the System to Deter and Address Criminal Acts Committed by Contractor Employees Accompanying Armed Forces Overseas," Public Contract Law Journal 38 (2009): 509, 514.

15 10 U.S.C. $\S \S 801-946$ (2006).

16 Cullen, "Out of Reach," 515; quoting Walter Pincus, "Iraq Bans Security Contractor," Washington Post (18 September 2007), A01. 
the military. Especially in weak or developing nations, "the hiring of [PSC] services may undermine the regime's control over the military." ${ }^{17}$ In other words, the state relies upon the private force instead of its regular troops; a lack of confidence results; the state mistrusts its armies, and the army brooks its government.

Second, copious amounts of anecdotal reports exist that show that PSCs have been hiring away military personnel, especially Special Forces members, and offering them higher salaries than the regular military can offer. ${ }^{18}$ For example, the pay range of PSC contractors ranges anywhere from USD 500 to 1,500 per day. ${ }^{19}$ By means of comparison, the average junior enlisted U.S. military member earns about USD 66 to 100 per day. ${ }^{20}$ While no hard data exist on PSCs' impact on the regular armed forces' retention, the stark difference in pay nevertheless saps the military's competitive advantage. ${ }^{21}$

Third, according to systematic data, contractors violate laws and get away with it. And people notice. Based on one survey conducted in 2008, 20 percent of armed forces members believed armed contractors were not respectful of international law. As for U.S. Department of State personnel, when polled, 40 percent thought PSC contractors violated international law. ${ }^{22}$ However, violations are not necessarily dangerous to the mission; they become troubling only when coupled with impunity or indifference. Despite the efforts of Congress to address the problem of adequately disciplining contractors and deterring them from committing misconduct, 30 percent of military and 26 percent of State Department members surveyed in 2008 claimed that armed contractors are given free rein to misbehave with little accountability. ${ }^{23}$

These factors make it more difficult not only to accomplish the war-fighting mission in dangerous territories but also to maintain the United States' credibility and that

17 Fred Schreier and Marina Caparini, Privatising Security: Law, Practice and Governance of Private Military and Security Companies (Geneva: DCAF, 2005), 61; available at www.dcaf.ch/publications/kms/details.cfm?lng=en\&id=18346\&nav1=5.

18 Elsea, Schwartz, \& Nakamura, Private Security Contractors in Iraq, 37.

19 Ibid., 5; citing David Barstow, "Security Companies: Shadow Soldiers in Iraq," New York Times (19 April 2004).

20 See Military Pay Tables, available at www.dfas.mil/militarypay/militarypaytables.html (last visited 28 November 2009). The calculation above used an E-4 enlisted member as the test case. He would earn USD 1,920.90 per month in base pay; this would not include hazard pay, a housing allowance, or other sources of income.

21 But the problem may not be as dire as some claim. In Iraq, according to a 30 June 2009 report, there were 623 armed American PSC contractors compared to 1,029 Iraqi contractors and 11,580 third-country nationals. With a total of 13,232 armed contractors in Iraq, 88 percent were third-country nationals. In contrast, in Afghanistan, among a total of 5,165 armed security contractors, 4,895 (95 percent) were local Afghanis. Schwartz, The Department of Defense's Use of Private Security Contractors in Iraq and Afghanistan, 6-9.

22 Ulrich Petersohn, "Private Security Companies and Counterinsurgency Operations," paper presented at the annual conference of the American Political Science Association (Toronto, 3-6 September 2009), 5-6; available at http://papers.ssrn.com/sol3/papers.cfm?abstract $\mathrm{id}=1449312$.

23 Ibid., 18. 
of its armed forces. In fact, campaigns against insurgencies are at their core battles of credibility; the occupying force can withdraw only after it has successfully propped up the local government. "The presence of a massive contracting force, seeming to be more powerful and outside the rule of law, shows the local populace the exact opposite. They both affront and simultaneously undermine the regime within local eyes." ${ }^{24}$

In sum, the chief goal of counter-insurgency operations like those in Iraq and Afghanistan is to establish a stable government, which permits occupying troops to leave. Unaccountable contractors that undermine the rule of law stand in the way of achieving that objective. Faced with this problem, the U.S. Department of Defense (DoD) acted. It promulgated various administrative changes: security firms must now register with the Iraqi government; military commanders are charged with ensuring that PSC guardsmen obey the laws of armed conflict; and commanders are required to prevent contractors suspected of committing felonies from leaving the country. ${ }^{25}$ And while there are no universal operating procedures for the PSC industry, the Department of Defense issued an Instruction establishing policies for managing PSCs during contingency operations. ${ }^{26}$

However, administrative remedies alone lack the teeth required to address the concerns raised by the above-mentioned survey, which found that a significant portion of U.S. servicemembers and State Department officials feel that contractors break laws and get away with it. But the follow-up question must necessarily be "What laws?" Or, more to the point, "Whose laws?"

\section{Responses to the Perceived Impunity of PSCs}

Still drawing on the Nisoor Square incident in Baghdad discussed above, assume that a U.S. PSC contractor murders a native of the country in which the PSC operates, but at the time of the murder there are no native laws to speak of. Or consider that, for whatever reason, those native laws do not apply to occupying forces. ${ }^{27}$ If one can accept the proposition that justice must be done in order to deter further misconduct that would jeopardize military campaigns and drain the morale of regular troops, then there are three avenues by which the PSC shooter could be criminally prosecuted: international

24 Peter W. Singer, “Can't Win With 'Em, Can't Go to War Without 'Em: Private Military Contractors and Counterinsurgency," Brookings Institution Foreign Policy Paper Series No. 4 (September 2007): 12; available at http://www.brookings.edu/papers/2007/0927militarycon tractors.aspx.

26 U.S. Department of Defense, Instr. 3020.50, Private Security Contractors (PSCs) Operating in Contingency Operations (22 July 2009).

27 This is in fact the background for the Nisoor Square killings: at the time of the incident, contractors were exempt from Iraqi laws for acts related to their contracts. Coalition Provisional Authority (CPA) Order 17, Status of the Coalition, Foreign Liaison Missions, Their Personnel and Contractors, 23 June 2003; available at www.cpa-iraq.org/regulations/ 20040627_CPAORD_17_Status_of_Coalition_Rev_with_Annex_A.pdf. 
law, the extraterritorial application of U.S. law, or an extension of U.S. military law over contractors accompanying armed forces.

\section{International Law}

Although the legal status of security contractors is murky, and commentators are undecided as to whether they would be treated as mercenaries or civilians if caught by an enemy, even as civilian actors they are subject to international law. ${ }^{28}$ There exists precedent that civilian contractors are "subject to international humanitarian law and prosecution for war crimes, including murder and crimes against humanity."29 During World War II, the Japanese Army traveled with contractors who guarded Allied prisoners of war; when the war ended, the most notorious of these contractors were successfully tried for war crimes. But there is one obvious difference between the Japanese contractors and modern-day PSCs: someone was actually willing to prosecute them. ${ }^{30}$

Even before the administration of George W. Bush, the U.S. had spurned the jurisdiction of international courts. Most notably, the U.S. is not a member of the International Criminal Court (ICC) in The Hague. ${ }^{31}$ President Obama's policies regarding the ICC are as yet unclear, but even during the Bush Administration the objections eventually softened. The U.S. did not object to the ICC prosecuting war crimes in Darfur; in fact, Congress explicitly acknowledged its authority to do so. ${ }^{32}$ The propriety of trying contractors before the ICC may be debated, but currently the U.S. would probably object, which undermines the need for swift, tailored justice in order for commanders on the ground to maintain good order and discipline. ${ }^{33}$

Another potential avenue for prosecution under international law-one that is appropriate to the proposed scenario, but is highly unlikely to be employed-are courts exercising universal jurisdiction on the basis that some principles apply universally and

28 "The 1949 Geneva Conventions distinguish between members of the armed forces (combatants) and civilians. Contractors are considered to be civilians authorized to accompany the force in the field. ... Contractors may lose their legal protection if they are used in direct support of military operations; in such cases they would become subject to direct attack so long as they directly participated in the hostilities." Human Rights Watch, "Q\&A: Private Military Contractors and the Law," 21 October 2004; available at www.globalpolicy.org/ component/content/article/167-attack/35796.html.

29 Robin Rowland, "Private Military Contractors Subject to the Rule of Law: Second World War Gonzoku Provide Precedent," CBC News (updated 15 October 2007); available at www.cbc.ca/news/background/iraq/military-contractors.html.

Ibid.

31 Alex Koppelman and Mark Benjamin, "What Happens to Private Contractors Who Kill Iraqis? Maybe Nothing," Salon.com (18 September 2007); available at www.salon.com/ news/feature/2007/09/18/blackwater/index.html.

32 H.R. 726, 100th Cong. (2007).

33 On the other hand, other states have signed onto the Rome Treaty and acceded to the ICC; their contractors may very well be more likely to stand trial for violations of international humanitarian law. 
certain laws rise to the level of jus cogens. In other words, such courts would operate on the presumption that war crimes may be prosecuted by any state against any actor because the conduct is so reprehensible. This area of international law is far from settled. Even prosecution-happy Spain and Belgium are changing their ways regarding their jurisdictional grants, requiring some tie to Spanish or Belgian victims or perpetrators. $^{34}$

Thus, an approach based purely in international law would require a watershed shift in how countries, including the U.S., view extrajudicial killings, torture, and other actions that could be classified as war crimes. Because of this required change, this article concludes that relying on the international tribunal system is not the best approach for ensuring the swiftest application of justice and satisfying the concerns of commanders and regular troops. However, international law is of chief importance in determining whether the U.S. could bring PSC contractors into its courts for violations of the laws of war or committing acts of torture.

\section{Extraterritorial Application of United States Law}

Most crime is territorial: trials are held and sentences adjudged in the state where the wrong occurred and under its criminal laws. ${ }^{35}$ As a general rule, no nation's laws apply

34 See Steve Kingstone, "Spain Reins in Crusading Judges," BBC News (25 June 2009); available at http://news.bbc.co.uk/2/hi/europe/8119920.stm. Human Rights Watch, Belgium, "Universal Jurisdiction Law Repealed" (1 August 2003); available at www.hrw.org/en/news/ 2003/08/01/belgium-universal-jurisdiction-law-repealed. See also Reed Brody, "The World Needs Spain's Universal Jurisdiction Law," Human Rights Watch (27 May 2009); available at http://www.hrw.org/en/news/2009/05/27/world-needs-spain-s-universal-jurisdiction-law (discussing the possible repeal of Spain's universal jurisdiction law).

35 The authoritative treatise on the extraterritorial application of U.S. law is Anthony Colangelo, "Constitutional Limits on Extraterritorial Jurisdiction: Terrorism and the Intersection of National and International Law," Harvard International Law Journal 8 (2007): 121, 122-23. What this essay addresses is only a snippet of Colangelo's larger article. Colangelo concludes, however, that "while the present constitutional landscape prescribes certain structural and due process limits on the United States' ability to project and apply extraterritorially its anti-terrorism laws, doctrines of international law intersect with the Constitution to avoid these limits, leaving the United States virtually unconstrained to extend the core panoply of its anti-terrorism laws to foreigners abroad." Colangelo goes on to write: "the international legal doctrine of universal jurisdiction interacts with sources of congressional lawmaking authority to overcome any potential constitutional obstacles to the extraterritorial application of U.S. law to the perpetrators of 'universal' crimes under international law; crimes that include terrorist acts like the bombing of public places, infrastructure, transportation systems, airports and aircraft, as well as hijacking, hostage taking, and even financing foreign terrorist organizations. However, constitutional limits - most notably those contained in the Fifth Amendment's Due Process Clause - do restrict the ability of the United States to apply extraterritorially those U.S. code provisions outlawing conduct that is not subject to universal jurisdiction under international law, such as providing material assistance to, or receiving military training from a foreign terrorist organization." 
within the territory of another. ${ }^{36}$ However, U.S. federal law does at times apply abroad; its extraterritorial mandate derives from the Constitution itself, which permits Congress to, among other things, "regulate commerce with foreign nations" and "define and punish piracy and felonies committed on the high seas, and offenses against the laws of nations...."37 Most importantly, it permits Congress to make all laws "necessary and proper" for executing the above enumerated powers. ${ }^{38}$

However, the Constitution limits the manner in which extraterritorial application may take effect. First, the due process clause of the Fifth Amendment prevents "the application of federal criminal laws in the absence of a connection between the crime, the defendant, and the United States." ${ }^{39}$ But these are not high hurdles. The extraterritorial application of federal law is "said to be [more] a matter of intent than of power, of statutory construction rather than constitutional limitation." ${ }^{40}$ There exists a general presumption against the extraterritorial application of U.S. law. ${ }^{41}$ This presumption guards against conflicts between domestic law and the laws of host nations, especially considering that Congress usually intends to act solely within its domestic sphere of influence. ${ }^{42}$ However, this presumption may be surmounted when Congress is clear and says that a given law applies abroad. Courts may also drill down and find "clear evidence" of Congress' intent by examining the statute itself, its structure, and its legislative history. ${ }^{43}$ In any case, assuming that Congressional intent is clear or such intent is divined, "courts will find no offense to international law as long as the application [of

This article agrees, and ultimately recommends a similar expansion of domestic law; however, its recommendation is constrained only to deterring and prosecuting abuses by security contractors, rather than a full-spectrum application of U.S. domestic law against non-state actors engaged in terrorism.

Charles Doyle, Terrorism and Extraterritorial Jurisdiction in Criminal Cases: Recent Developments in Brief, Congressional Research Service Report No. RS21306 (Washington, D.C.: Congressional Research Service, updated 6 September 2002), 1.

Constitution of the United States, Article I, § 8, clauses 3, 10.

38 Ibid., at clause 18.

39 Doyle, Terrorism and Extraterritorial Jurisdiction in Criminal Cases, 1.

40 Ibid.

41 E.E.O.C. v. Arabian American Oil Co., 499 U.S. 244 (1991).

42 Foley Bros., Inc. v. Filardo, 336 U.S. 281, 285 (1949). The classic example of arresting someone for smoking marijuana in Amsterdam for violating U.S. drug laws suffices to prove this point. However, there is no presumption against extraterritorial application of U.S. laws regarding statutes criminalizing actions against the U.S. government itself. U.S. v. Bowman, 260 U.S. 94 (1922); but see Kollias v. D \& G Marine Maintenance, 29 F.3d 67, 71 (2d. Cir 1964), cert. denied, 513 U.S. 1146 (1995) (holding that Bowman ought to be read narrowly, such that "only criminal statutes, and perhaps only those relating to the government's power to prosecute wrongs committed against it, are exempt from the presumption.")

43 United States. v. Gatlin, 216 F.3d 207, 211-12 (2d Cir. 2000). 
extraterritorial effect] features reasonable contacts between the crime and the nation asserting jurisdiction., ${ }^{4}$

But the law must exist before it can be applied. Currently, federal laws with extraterritorial application deal with crimes of violence against federal officials and employees, the theft or destruction of federal property, efforts to smuggle drugs or persons into the country, and aircraft hijacking. ${ }^{45}$ There are also federal laws against more common crimes like murder, rape, and robbery while on federal installations; they potentially apply abroad as well. ${ }^{46}$ Additionally, contractors may be prosecuted under the War Crimes Act of $1996^{47}$ or the federal anti-torture statute. ${ }^{48}$ However, to this date,

44 Doyle, Terrorism and Extraterritorial Jurisdiction in Criminal Cases, 2. Reasonable contacts generally fall into five categories: (1) the objective territorial principle, where external conduct has a substantial effect within the asserting country, such as, potentially, conspiracy to commit terrorism; (2) the protective principle, where outside conduct is directed against the country's national security; (3) the nationality principle, where the offender is one of the country's nationals; (4) the passive personality principle, where the victim is one of the country's nationals; and (5) the universality principle, where the conduct violates jus cogens and may be prosecuted by any state.

Ibid.

46 Their application is limited to U.S. governmental enclaves abroad. For crimes committed by foreign nationals, there is still a lingering question as to whether they may come within the territorial jurisdiction of the United States. Ibid., 3.

47 The War Crimes Act defines a war crime as any grave breach of the 1949 Geneva Conventions, like torture or inhumane treatment; or any violation of Common Article 3 of the Geneva Conventions (which not only includes torture but also "outrages upon personal dignity" and "humiliating and degrading treatment"). It applies anywhere and whether the perpetrator is a member of the U.S. regular armed forces or a U.S. national. Thus, it does not apply to foreigners. However, the statute does apply if the victim falls within those categories. 18 U.S.C. $\S 2441$.

48 This statute (18 U.S.C. $\$ 2340$ ) criminalizes the act of torture, even when committed outside the United States. It intends to implement the Convention Against Torture (which the U.S. ratified in 1994 with certain reservations), but contains some differences in its definition of torture:

The Torture Act defines “'torture' [as] an act committed by a person acting under the color of law specifically intended to inflict severe physical or mental pain or suffering (other than pain or suffering incidental to lawful sanctions) upon another person within his custody or physical control." The law then limits the scope of "severe mental pain or suffering" to mean "prolonged mental harm" resulting from (i) the intentional infliction or threatened infliction upon the victim or a third person of "severe physical pain or suffering"; (ii) the administration or threatened administration upon the victim or a third person of "mind-altering substances or other procedures calculated to disrupt profoundly the senses or the personality"; or (iii) the "threat of imminent death" of the victim or a third person. Unlike the U.S. law, the Torture Convention does not require that mental harm be "prolonged," nor does the Convention limit the types of causes for mental harm.

See Human Rights First, "Security Detainees/Enemy Combatants: U.S. Law for Prosecuting Torture and Other Serious Crimes Committed by Civilians Abroad"; available at http://humanrightsfirst.org/us_law/detainees/us_torture_laws.aspx. 
there have been no completed trials under either the torture statute or the War Crimes Act. $^{49}$

Thus, the surest means by which to apply U.S. law extraterritorially to PSC contractors is via the Military Extraterritorial Jurisdiction Act of 2000 (MEJA) ${ }^{50}$ Congress passed MEJA out of concern for the "lack of U.S. criminal jurisdiction [over potential crimes] committed by civilians, including military dependents and contractors accompanying U.S. armed forces overseas." ${ }^{51}$ In fact, MEJA was intended to close the gap that other avenues of extraterritorial application of U.S. law could not effectively bridge.

In United States v. Gatlin ${ }^{52}$ the accused was a military spouse who raped and impregnated his thirteen-year-old stepdaughter while living in Germany. The U.S. asserted jurisdiction, arguing that an overseas military installation was within the special maritime and territorial jurisdiction of the United States. ${ }^{53}$ The U.S. Court of Appeals for the Second Circuit disagreed, holding that extraterritorial jurisdiction did not exist for the rape, ${ }^{54}$ thus setting it apart from other circuits, which would find jurisdiction. ${ }^{55}$ The split called for Congressional action, and Congress passed MEJA.

The premise of MEJA is simple. It explicitly creates a separate federal criminal offense for any act committed outside the U.S. if the act would constitute a felony within the jurisdiction of the United States. ${ }^{56}$ Those covered by MEJA include: those persons subject to the Uniform Code of Military Justice (UCMJ), or military law; anyone employed by or accompanying the armed forces outside the United States; and contractor employees of any federal agency or provisional authority whose employment supports the mission of the U.S. Department of Defense overseas. ${ }^{57}$

However, MEJA is imperfect. By its definition, it does not apply to nationals of the country in which the U.S. forces are stationed, although it may apply to third-country nationals. ${ }^{58}$ In fact, DoD now requires that third-country nationals (which, as noted above, make up a substantial part of the PSC contractor force in Iraq) be advised of

49 Ibid.

50 Military Extraterritorial Jurisdiction Act of 2000, Pub. L. No. 106-523, 114 Stat. 2488 (2000) (codified as amended at 18 U.S.C. $\S \S 3261-67$ (2006)).

51 Cullen, "Out of Reach," 531. Previously, there had been unsuccessful attempts to court-martial military dependents, specifically spouses; this reach of military law was considered unconstitutional. Reid v. Covert, 354 U.S. 1 (1957); Kinsella v. United States ex rel. Singleton, 361 U.S. 234 (1960).

52 United States. v. Gatlin, 216 F.3d 207, 211-12 (2d Cir. 2000).

53 As defined by 18 U.S.C. $\S 7$. See Gatlin, 216 F.3d. at 216.

54 Gatlin, 216 F.3d. at 223.

55 Doyle, Terrorism and Extraterritorial Jurisdiction in Criminal Cases, 3.

5618 U.S.C. $\$ 3261$ (a).

57 Cullen, "Out of Reach," 532.

58 Ibid., citing U.S. Department of Defense, Instr. 5525.11, Criminal Jurisdiction Over Civilians Employed By or Accompanying the Armed Forces Outside the United States, Certain Service Members and Former Service Members (3 March 2005); available at www.dtic.mil/ whs/directives/corres/pdf/552511p.pdf. 
potential criminal jurisdiction under MEJA "before accepting employment and immediately upon arriving at their work locations overseas. ${ }^{, 59}$ Nor does it apply to crimes less than felonies. There are also difficulties in its implementation: it contains highlevel procedural requirements as prerequisites - for example, "military criminal investigators ... are required to forward their reports to the legal office of the responsible combatant command. ${ }^{\circ 0}$ This may prove to be an onerous burden.

But the most glaring obstacle is that MEJA is simply not responsive. According to one commentator, "MEJA is poorly suited to serve as an effective tool to shape contractor employee behavior and deter criminal acts ... because its design makes it nonresponsive to the deterrence needs of military commanders...." $" 61$ MEJA requires coordination between the military and the Department of Justice (DoJ), as U.S. Attorneys ultimately make the final call about whether to prosecute; in so doing, they must "consider resources available to conduct the prosecution," as a trial would come from their budget, and "should be expected to consider the seriousness of the crime; the difficulty of gathering evidence; difficulties of securing testimony from witnesses located in, and perhaps nationals of, an area of military hostilities; and competing caseloads and priorities in the U.S. Attorneys' own districts. ${ }^{.62}$ In sum, MEJA prosecutions are (and given these constraints, probably should be) rare.

Nor do MEJA prosecutions necessarily address those criminal acts that commanders on the ground see as particularly problematic. Those commanders can direct investigations according to their needs; they cannot, however, direct which U.S. Attorney will receive the MEJA case and cannot decide whether a prosecution will occur. An investigation could be followed by nothing. Since its implementation in 2000, only twelve indictments have been issued under MEJA, and only one case has been tried to conviction. $^{63}$

The ultimate advantage of MEJA is that its implementation is relatively easy-after all, it is only a statement of extraterritorial effect - and its convictions share the legitimacy that other federal convictions enjoy. ${ }^{64}$ That legitimacy obviates any constitutional issues that might arise when trying civilians in courts-martial. MEJA is simple; however, in has not proven useful in actually deterring criminal conduct. Commander-directed investigations and subsequent prosecutions under the UCMJ are another, more responsive option to situations where private security contractors commit crimes overseas.

\section{Applying Military Law to PSC Contractors}

In theory, the Uniform Code of Military Justice provides the fastest, easiest way by which to prosecute and discipline contractors. At the time of MEJA's enactment, only

\footnotetext{
59 Ibid.

60 Ibid., 533.

61 Ibid.

62 Ibid., 534-35.

63 Ibid., 536.

64 Ibid., 540.
} 
U.S. armed forces members were typically subject to the UCMJ. ${ }^{65}$ After the introduction of the UCMJ in 1950, the military occasionally asserted jurisdiction over civilians. But the Supreme Court of the United States worked swiftly to limit its application, finding that courts-martial lacked safeguards "compared to federal civilian trials, including the rights to indictment by a grand jury, a trial before a jury of one's peers, and the right to have the case tried before a judge with life tenure. ${ }^{, 66}$ As courts-martial provided none of these protections, the court held that Congress could not subject civilians to courts-martial jurisdiction. ${ }^{67}$

As time progressed, the military occasionally continued to try its hand at bringing civilians, including military spouses, before courts-martial. ${ }^{68}$ The result was the same. ${ }^{69}$ The court "again emphasized that given its plain meaning, Congress' power to make rules for the government of the armed forces is limited to actual members of the armed forces 'and not their civilian wives, children, and other dependents.", 70

However, none of these Supreme Court decisions involved contractors. Nor did the misconduct occur anywhere near active hostilities. The Supreme Court has "never spoken directly to the issue of court-martial jurisdiction over contractor employees, or to the issue of jurisdiction during active military hostilities as contemplated by [the] UCMJ ... which provides for court-martial jurisdiction over persons serving with or accompanying an armed force ... during time of war.",71

Only the Court of Military Appeals, now known as the Court of Appeals for the Armed Forces, has ruled on the issue; it overturned a court-martial conviction over a contractor employee in Vietnam accompanying regular troops. ${ }^{72}$ However, it based its rationale not on whether Congress could authorize court-martial jurisdiction over contractors, but whether jurisdiction was effectively established under Article 2(a)(10) of

65 See 10 U.S.C. $§ 802(a)(10)$. This statute establishes jurisdiction "[i]n time of declared war or a contingency operation, [over] persons serving with or accompanying an armed force in the field.

66 United States ex rel. Toth v. Quarles, 350 U.S. 11, 16-18 (1955).

67 Ibid., 15. The court noted that Congress certainly had authority to promulgate the UCMJ under its grant to regulate the land and naval forces. U.S. Const. Art. I, $\S 8$. But it noted that the language of the Constitution would "seem to restrict court-martial jurisdiction to persons who are actually members or parts of the armed forces." Toth, 350 U.S. at 15.

68 Jurisdiction was established under 10 U.S.C. $\S 802(a)(11)$. This provides jurisdiction "[s]ubject to any treaty or agreement to which the United States is or may be a party or to any accepted rule of international law, persons serving with, employed by, or accompanying the armed forces outside the United States and outside the Commonwealth of Puerto Rico, Guam, and the Virgin Islands."

69 See Reid v. Covert, 354 U.S. 1 (1957).

70 Cullen, "Out of Reach," 522 (quoting Reid, 354 U.S. at 20). However, Reid was a capital case. Later on, the Supreme Court answered negatively whether civilian dependents could be court-martialed for non-capital offenses. Kinsella v. United States ex rel. Singleton, 361 U.S. 234 (1960).

71 Cullen, “Out of Reach,”522-23; see also 10 U.S.C. $§ 802(a)(2)(10)$.

72 United States v. Averette, 19 C.M.A. 363 (1970). 
the UCMJ. Since Vietnam was not actually a declared war, the answer was No. Thus, the military "could only exercise jurisdiction over civilians during a time of formally declared war." "73 If war were declared, then "consideration of the constitutional limitations" would follow. ${ }^{74}$

Of course, Congress has not declared war since World War II, rendering Article 2(a)(10) jurisdiction almost moot. ${ }^{75}$ But Congress did address the problem of contractor crimes. In Section 552 of the John Warner National Defense Authorization Act for Fiscal Year 2007, it expanded Article 2(a)(10) jurisdiction to include contingency operations. ${ }^{76}$ Contingency operations would have included Vietnam; they also include all undeclared wars since World War II. ${ }^{77}$ This jurisdictional expansion "obviates the requirement of a declaration of war by requiring only that civilians be with the armed forces during a contingency operation." 78

One commentator notes that the jurisdictional grant shared by Article 2(a)(10) and MEJA are basically synonymous: any person "charged [under the UCMJ] with a crime while 'accompanying the armed force' and 'in a time of declared war or contingency operation' ... largely falls within the same group as 'civilians, both U.S. citizens and foreign nationals, who commit criminal acts while employed by or accompanying the Armed Forces outside the United States" who are charged via MEJA. ${ }^{79}$ Because of this stark overlap, the U.S. Secretary of Defense, Robert Gates, issued a memorandum

73 Dan E. Stigall, “An Unnecessary Convenience: The Assertion of the Uniform Code of Military Justice ("UCMJ") Over Civilians and the Implications of International Human Rights Law," Cardozo Journal of International and Comparative Law 17 (2009): 59, 71.

74 Averette, 19 C.M.A. at 365.

75 Cullen, "Out of Reach," n. 105; citing John Alan Cohen, "Legal War: When Does It Exist, and When Does It End?" Hastings International and Comparative Law Review 27 (2004): 221, 222; Michael D. Ramsey, "Presidential Declarations of War," U.C. Davis Law Review 37 (2003): 321, 322 (noting that the U.S. has fought only undeclared wars since the end of the Second World War).

76 John Warner National Defense Authorization Act for Fiscal Year 2007, Pub. L. No. 109-364, $\S 552,120$ Stat. 2217 (2006).

77 A contingency operation is defined as a military operation that: (a) is designated by the Secretary of Defense as an operation in which members of the armed forces are or may become involved in military actions, operations, or hostilities against an enemy of the United States or against an opposing military force; or (b) results in the call or order to, or retention on, active duty of members of the uniformed services under Section 688, 12301(a), 12302, 12304,12305 , or 12306 of this title, Chapter 15 of this title, or any other provision of law during a national emergency declared by the President or Congress. 10 U.S.C. $§ 101(\mathrm{a})(13)$. Stigall, "An Unnecessary Convenience," 71.

79 Ibid. There are gaps, however: MEJA only applies to felony-level crimes, and the UCMJ criminalizes certain types of conduct, such as violating a lawful order and committing adultery, that is not a violation of federal law and therefore not subject to prosecution via MEJA. 
to military commanders regarding how to proceed.$^{80}$ In short, he instructed commanders to gather evidence for potential prosecution, but to inform the Department of Justice about possible prosecution under MEJA. If the Department of Justice failed to act (as it almost always does in MEJA cases), commanders were directed to be prepared to assert court-martial jurisdiction.

So far, one contractor has been successfully court-martialed and convicted under the UCMJ. ${ }^{81}$ But that conviction has not been reviewed by a higher court, so the constitutional murkiness regarding the court-martial of contractors remains. ${ }^{82}$ While Congress may have navigated around the obstacle of not declaring war, constitutional questions remain regarding whether bringing contractors before courts-martial conforms to precedent. The Supreme Court held that "Congress cannot subject civilians ... to trial by court-martial. They, like other civilians, are entitled to have the benefit of safeguards afforded in the regular courts authorized by Article III of the Constitution." 83 However, none of these precedents dealt with wartime scenarios. And Justice Black also quipped in dicta that "the extraordinary circumstances present in an area of actual fighting have been considered sufficient to permit punishment of some civilians in that area by military courts under military rules., ${ }^{~} 4$

Relying on those case studies, Colonel Kevan Jacobson, a U.S. Army prosecutor, suggests that "Congress has deemed it proper ... to subject to courts-martial jurisdiction civilian personnel who were closely associated with the Armed Forces. ${ }^{, 85}$ Jacobson elaborates, noting that Supreme Court precedent barring the court-martial of civil-

${ }^{80}$ Memorandum from the Secretary of Defense to the Secretaries of the Military Departments et al., "UCMJ Jurisdiction over DoD Civilian Employees, DoD Contractor Personnel, and Other Persons Serving with or Accompanying the Armed Forces Overseas During Declared War and in Contingency Operations" (10 March 2008).

81 See Kevin Lanigan, "U.S. Military Court-Martialing Civilian Contractor Ali While DoJ Slumbers," Jurist (updated 19 May 2008); available at http://jurist.law.pitt.edu/hotline/2008/ 05/us-military-to-court-martial-ali-while.php. See also Phillip Carter, "First Contractor Prosecution Ends in Guilty Plea," Slate.com (24 June 2008); available at www.slate.com/blogs/ blogs/convictions/archive/2008/06/24/first-contractor-prosecution-ends-in-guilty-plea.aspx.

82 The Court of Appeals for the Armed Forces denied the accused's writ appeal. See Dwight Sullivan, "CAAF Denies Court-Martialed Civilian's Writ Appeal," CAAFLOG.com (7 November 2008); available at http://www.caaflog.com/2008/11/07/caaf-denies-court-martialedcivilians-writ-appeal.

83 United States ex rel. Toth v. Quarles, 350 U.S. 11, 23 (1955).

84 Reid v. Covert, 354 U.S. 1, 33 (1957).

85 Kevan Jacobson, "Restoring UCMJ Jurisdiction Over Civilian Employees During Armed Hostilities," U.S. Army War College Strategy Research Project (Carlisle, PA: USAWC, 15 March 2006), 3; available at www.strategicstudiesinstitute.army.mil/pdffiles/ksil374.pdf. This paper is especially prescient, noting that an amendment to Article 2(a)(10) recognizing that modern war is no longer formally declared would extend court-martial jurisdiction over certain civilians. 
ians does not address the contractor problem ${ }^{86} \mathrm{He}$ finally addresses, by means of trotting out procedural safeguards, differences between courts-martial and civilian trials, and ultimately concludes that "today's military justice system is well equipped and structured to guarantee due process of law to any accused, whether a uniformed member of the service or a civilian who supports that service member in a combat theater." ${ }^{87}$

In conclusion, however, UCMJ jurisdiction has notable pros and cons: it is "portable and responsive to the needs of military officials responsible for the safety and welfare of deployed personnel," but it is arguably constitutionally deficient when applied to contractors. ${ }^{88}$ The military justice system is "designed to deploy," and within deployed environments, commanders would have ready access to evidence and witnesses - as well as prosecutors and defense counsel, who also deploy. ${ }^{89}$ But whether or not one can predict how the Supreme Court might ultimately address the question, commanders will be wary of using the process. The one test case that exists was not subject to higher review. And those deployed prosecutors will surely advise commanders against initiating court-martial proceedings in serious cases. ${ }^{90}$

\section{Wrangling the Cowboys: A Two-Tiered Approach}

The best approach is a simple one, but it does require Congressional action. Fortunately, the courses of action that would most improve the situation for today's commander in the field are those with firm precedent. The trial of civilian contractors under the UCMJ will likely be subject to challenge on constitutional grounds. ${ }^{91}$ The surest way to prosecute is MEJA, a law that has mostly been ignored. ${ }^{92}$ One commentator notes that MEJA's track record is abysmal, mainly because of the "significant practical

86 Ibid., 14, noting that the litany of cases denying court-martial jurisdiction over civilians were based on Article 2(a)(11) of the UCMJ, not Article 2(a)(10)), and further noting that the military courts addressed the issue squarely in United States v. Averette, 19 C.M.A. 363 (1970).

87 Ibid., 18.

88 Cullen, "Out of Reach," 538.

89 Ibid.

90 One appellate-level decision could overturn all convictions based on a jurisdictional grant under Article 2(a)(10). While some judge advocates may relish the opportunity to blaze a legal trail, ethics would require they advise commanders, who initiate prosecutions under the UCMJ, that a conviction might not "hold." Of course, speaking practically, if the ultimate goal is confinement or suspension of pay, those sentences may expire entirely before the Supreme Court ever hears the case.

91 Elsea, Schwartz, \& Nakamura, Private Security Contractors in Iraq, 27.

92 Or inapplicable. See "Pentagon Letter Complicates Blackwater Case," Washington Post (3 February 2009), noting that a Deputy Secretary of Defense wrote a memorandum stating that Blackwater employees, during the Nisoor Square incident, "were not engaged in employment in support of the DoD mission" and that therefore federal prosecutors lacked jurisdiction under MEJA to charge them. 
hurdles a federal prosecutor must overcome in order to successfully prosecute these cases." 93

This is something Congress must fix. MEJA will never be a universal panacea; it should not be used to prosecute war crimes like those arguably committed by Blackwater personnel in Baghdad. ${ }^{44}$ But it should be more widely used, and it should cover companies like Blackwater. As drafted, only forces "supporting the mission" of the Department of Defense fall under U.S. jurisdiction. Many PSCs, however, are under contract to the Department of State. ${ }^{95}$ Ultimately, U.S. foreign policy and the U.S. military itself are "hurt by the confusion caused by these essentially independent combat forces ... with the imprimatur of the U.S. government. ${ }^{, 96}$ Without the swift application of justice, discipline suffers.

Therefore, Congress should make two changes to increase the scope of MEJA. First, it must ensure MEJA applies to any contractor accompanying the armed forces, not simply those employed by the Department of Defense. Second, it must lower the threshold for prosecution and give DoJ the option - however rarely it might be usedto bring charges against contractors for crimes not rising to the felony level.

Additionally, Congress must grease the wheels of the criminal justice system as well. As it stands, commanders are charged with conducting initial investigations. Investigations then go to the Domestic Security Section of DoJ's criminal division. From there, they make their way to the appropriate U.S. Attorney's office, which makes a decision to prosecute; and such decision is back-channeled all the way back to the commander in the field. ${ }^{97}$ This takes time. While DoJ should ultimately make the final call on whether to prosecute, designated district courts should assume ownership over MEJA cases in deployed environments.

For example, one district court could "own" Iraq. Pumping dollars and manpower into the corresponding U.S. Attorney's office, including establishing personnel specializing in MEJA, would streamline the process. Commanders would benefit from a direct link to the office responsible for prosecuting offenses they investigate; U.S. Attorneys would equally benefit from building a working relationship with senior military officials, investigators, and prosecutors.

To effectively create that kind of relationship, DoD and DoJ should accomplish more formal liaising. Provisions already exist to appoint military prosecutors as special

93 Victor Hansen, "Military Jurisdiction Over Civilians: Opening a Can of Worms?" Jurist (9 April 2008); available at http://jurist.law.pitt.edu/forumy/2008/04/military-jurisdiction-overcivilians.php.

94 See, e.g., Tara Lee, "MEJA for Street Crimes, Not War Crimes," DePaul Rule of Law Journal (August 2009); available at http://www.law.depaul.edu/students/organizations_journals/ student_orgs/lawrol/0908-issue-pdf/drolj-0908-article-lee-meja.pdf.

95 See, e.g., Aaron Zelinsky, "Close the Blackwater Loophole," Huffington Post (20 February 2009); available at http://www.huffingtonpost.com/aaron-zelinsky/close-the-blackwaterloop_b_168554.html.

Ibid.

97 Cullen, "Out of Reach," 540. 
Assistant U.S. Attorneys. They are routinely used to "prosecute crimes committed on federal military installations by persons not subject to the UCMJ." ${ }^{98}$ Usually, this means the not-so-glamorous world of traffic violations. But appointing a military prosecutor from the nearest military installation-someone able to share data (and often experiences) with the prosecutor and commander in the field-would afford the U.S. Attorney's office ready access to a resource more commonly versed in battlefield conditions and investigations. DoD could bridge the gap from the deployed environment to a base legal office on a military installation. Subsequently, DoJ could dispatch the local military prosecutor to act as a special Assistant U.S. Attorney. This would greatly lighten the workload for the U.S. Attorney's office; it would also allow the corps of military prosecutors commissioned into the various branches of the armed forces to make better use of their training and experiences. This process would ultimately energize the use of MEJA, permitting it to act as a deterrent, and ensure that PSC guardsmen accompanying the armed forces no longer escape the reach of United States law.

\section{Conclusion}

Addressing the problem of what to do with civilians accompanying the armed forces who break the law will not be easy, but with each legislative attempt, Congress seems to be getting better. It needs to act more swiftly, however, because the actions of lawbreaking PSC guardsmen negatively impact good order, discipline, and recruitment within the U.S. armed forces, and have a damaging influence on U.S. foreign policy. The UCMJ is not the right answer. Many of its provisions are military-specific: for example, how can rank be stripped from a contractor who does not possess one? Applying military laws to civilians, while expedient, raises enormous constitutional issues: creative wordplay on Congress' part cannot immediately resolve these questions. Thus, MEJA is the surest means by which to prosecute common offenders.

With a little more tailoring - and a lot more funding and manpower for the district courts assigned to accept cases from overseas areas of responsibility, and liaising between DoD and DoJ-MEJA will work. We currently have myriad laws but no desire to enforce them. When war crimes or violations of international law incorporated into U.S. domestic law occur, they should be prosecuted accordingly; when contractors commit felonies, MEJA should bring them back to stand trial in the United States. Shirking the issue leads to disaster for American troops at the operational and disciplinary level. The answer is not to make commanders sheriffs. Their job is to fight wars, not police cowboys roaming across the desert. Congress should instead provide federal marshals - both figuratively and literally - to enforce the rule of law in its courthouses.

98 Ibid., 541. 


\section{Bibliography}

Brody, Reed. The World Needs Spain's Universal Jurisdiction Law. Human Rights Watch, 2009.

Carter, Phillip. First Contractor Prosecution Ends in Guilty Plea. Slate.com, 2008.

Cohen, John Alan. "Legal War: When Does It Exist, and When Does It End?" Hastings International and Comparative Law Review 27 (2004): 221, 222.

Colangelo, Anthony. "Constitutional Limits on Extraterritorial Jurisdiction: Terrorism and the Intersection of National and International Law." Harvard International Law Journal 8 (2007): 121, 122-23.

Criminal Jurisdiction Over Civilians Employed By or Accompanying the Armed Forces Outside the United States, Certain Service Members and Former Service Members In Instr. U.S. Department of Defense, 2005.

Cullen, Stephen P.. "Out of Reach: Improving the System to Deter and Address Criminal Acts Committed by Contractor Employees Accompanying Armed Forces Overseas." Public Contract Law Journal 38 (2009): 509, 514.

Doyle, Charles. Terrorism and Extraterritorial Jurisdiction in Criminal Cases: Recent Developments in Brief In Congressional Research Service Report. Washington, D.C.: Congressional Research Service, 2002.

Elsea, Jennifer K., Mosche Schwartz, and Kennon H. Nakamura. Private Security Contractors in Iraq: Background, Legal Status, and Other Issues In Congressional Research Service Report. Washington, D.C.: Congressional Research Service, 2008.

Fainaru, Steve. "Where Military Rules Don’t Apply: Blackwater's Security Force in Iraq Given Wide Latitude by State Department." Washington Post (2007): A1.

Hansen, Victor. Military Jurisdiction Over Civilians: Opening a Can of Worms? Jurist, 2008.

Jacobson, Kevan. Restoring UCMJ Jurisdiction Over Civilian Employees During Armed Hostilities In U.S. Army War College Strategy Research Project. Carlisle, PA: USAWC, 2006.

John Warner National Defense Authorization Act for Fiscal Year 2007 In Pub. L., 2006.

Kingstone, Steve. Spain Reins in Crusading Judges. BBC News, 2009.

Koppelman, Alex, and Mark Benjamin. What Happens to Private Contractors Who Kill Iraqis? Maybe Nothing. Salon.com, 2007.

Lanigan, Kevin. U.S. Military Court-Martialing Civilian Contractor Ali While DoJ Slumbers. Jurist, 2008.

Lee, Tara. "MEJA for Street Crimes, Not War Crimes." DePaul Rule of Law Journal (2009).

Machiavelli, Niccolo. The Prince. London: Penguin, 1968. 
Military Pay Tables., 2009.

Paret, Peter. Makers of Modern Strategy from Machiavelli to the Nuclear Age. Princeton, NJ: Princeton University Press, 1986.

Pentagon Letter Complicates Blackwater Case. Washington Post (2009).

Petersohn, Ulrich. Private Security Companies and Counterinsurgency Operations In paper presented at the annual conference of the American Political Science Association. Toronto, 2009.

Pincus, Walter. "Iraq Bans Security Contractor." Washington Post (2007): A01.

Private Security Contractors (PSCs) Operating in Contingency Operations. U.S. Department of Defense, 2009.

Q\&A: Private Military Contractors and the Law. Human Rights Watch, 2004.

Raghavan, Sudarsan, and Thomas E. Ricks. "Private Security Puts Diplomats, Military at Odds." Washington Post (2007): A1.

Ramsey, Michael D.. "Presidential Declarations of War." U.C. Davis Law Review 37 (2003): 321, 322.

Rowland, Robin. Private Military Contractors Subject to the Rule of Law: Second World War Gonzoku Provide Precedent. CBC News, 2007.

Schreier, Fred, and Marina Caparini. Privatising Security: Law, Practice and Governance of Private Military and Security Companies. Geneva: DCAF, 2005.

Schwartz, Mosche. The Department of Defense's Use of Private Security Contractors in Iraq and Afghanistan: Background, Analysis, and Options for Congress In Congressional Research Service Report. Washington, D.C.: Congressional Research Service, 2009.

Singer, Peter W.. Can't Win With 'Em, Can't Go to War Without 'Em: Private Military Contractors and Counterinsurgency In Brookings Institution Foreign Policy Paper Series., 2007.

Status of the Coalition, Foreign Liaison Missions, Their Personnel and Contractors In Coalition Provisional Authority (CPA) Order., 2003.

Stigall, Dan E.. "An Unnecessary Convenience: The Assertion of the Uniform Code of Military Justice ("UCMJ") Over Civilians and the Implications of International Human Rights Law." Cardozo Journal of International and Comparative Law 17 (2009): 59,71 .

Sullivan, Dwight. CAAF Denies Court-Martialed Civilian's Writ Appeal. CAAFLOG.com, 2008.

Zelinsky, Aaron. "Close the Blackwater Loophole." Huffington Post (2009). 